\title{
ERCC1 Protein Expression
}

National Cancer Institute

\section{Source}

National Cancer Institute. ERCC1 Protein Expression. NCI Thesaurus. Code C99406.

An immunohistochemical diagnostic test to evaluate the expression of ERCC1 protein at the cellular level. 